\title{
MNC Flexibility And Post-Entry Mode Change: The Role Of Learning Ownership Regulations Through Network Embeddedness
}

Hua Ye, Ritsumeikan University, Japan \& Chongqing Medical University, China

\begin{abstract}
This paper proposed a theoretical framework that has linked together network embeddedness, learning ownership regulations, MNC flexibility, and post-entry mode change. Network embeddedness refers to the MNC subsidiary's relations with and reliance on the networks for learning ownership regulations. Learning ownership regulations refers to acquiring, interpreting or confirming ownership regulations of foreign investment in China. MNC flexibility is defined in this paper as the MNC's (Multinational Corporation's) ability to manage the risks and exploit the opportunities that arise from changing ownership regulations of foreign investment in China. Post-entry mode change is specified as the MNC subsidiary in China has been changed to wholly foreign-owned enterprise after initial entry as joint venture, including Chinese-foreign Cooperative Enterprise, Chinese-foreign JV and International JV. Japanese subsidiaries in China were studied, specifically three wholly foreign-owned enterprises in Shanghai. The case studies showed that network embeddedness contributes to learning ownership regulations, which in turn promotes MNC flexibility, which in turn facilitates post-entry mode change. In addition, MNC flexibility promoted by learning ownership regulations through network embeddedness can facilitate not only the change from joint venture to wholly foreign-owned enterprise, but also keeping as joint venture.
\end{abstract}

Keywords: Network Embeddedness; Learning; Foreign Institutional Knowledge; Flexibility; Entry Mode

\section{INTRODUCTION}

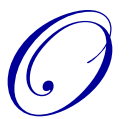

wnership regulations of foreign investment in China have been changing since the Opening Door Policy. The Joint Venture Law of 1979 allowed joint ventures (JVs) between foreign multinational corporations (MNCs) and state-owned enterprises (SOEs) for the first time. Chinese government launched the Law of Wholly Foreign-owned Enterprises in 1986, permitting MNCs to establish wholly foreignowned enterprises (WFOEs) for the first time. At that time, however, WFOEs were only allowed in a few industries. Many industries were still closed to foreign investment. Gradually, some were opened for WFOEs, while some were only opened for JVs with or without stipulating that Chinese SOEs should hold the majority share. Until 1995, the most prominent ownership laws "Regulations for Guiding the Direction of Foreign Investment" and its appendix "Catalogue for Guiding Foreign Investment in Industries" were issued. The former categorizes Chinese industries into those that are encouraged, permitted, restricted and prohibited for foreign investment and was revised in 2002. The latter (appendix) was revised in 1997, 2002, 2004 and 2007, respectively; thus they are called the Catalogues, which list industries in terms of encouraged, restricted, or prohibited categories. Those not listed belong to the permitted category. The investment in the encouraged category often enjoys the right to establish WFOEs, while that in the restricted category is often limited to JVs. The prohibited category refers to industries in which foreign investment is completely not allowed. During the revision of the Catalogues, more and more prohibited or restricted industries have upgraded to permitted, and even encouraged, categories, although some were downgraded from encouraged to restricted, or even to prohibited categories. In addition, other industry-specific regulations can have effect and may be given priority over the Catalogues. Thus, ownership laws and regulations in China are complex. 
Foreign institutional knowledge is the experiential knowledge of foreign government, institutional framework, rules, norms and values, including, among other things, the knowledge about changing ownership regulations of foreign investment. Since knowledge is the outcome of the learning process, knowledge about ownership regulations is the outcome of learning ownership regulations.

Relationship networks are becoming increasingly more involved in international business studies as firms are increasingly adopting network forms of organization and are subject to influences of non-economic factors (Powell, 1990). Networks are a source of learning and extracting information (Hagedoorn and Duysters, 2002), especially learning about markets and institutions in the host country (Rangan, 2000). Complying with Johanson and Vahlne (2009), networks in this paper are regarded as vehicles in learning institutional conditions, specifically, as an important source of learning ownership regulations. Thus, network embeddedness, the MNC subsidiary's relations with and reliance on both individual and organization-level networks, contributes to learning ownership regulations.

Flexibility is a multi-faceted concept and has been researched from various perspectives. Agreeing, but revising the definition of Bartlett et al's (2008) multinational flexibility, we utilize MNC flexibility to mean the MNC's ability to manage the risks and exploit the opportunities that arise from the changing of ownership regulations of foreign investment in China. Learning about risks and opportunities that arise from changing ownership regulations can be essential to managing these risks and exploiting these opportunities. As a result, learning ownership regulations promotes MNC flexibility.

Post-entry mode change refers to the MNC change of its mode of operation after initial entry into a foreign market. It is specified in this paper as the MNC changes to wholly foreign-owned enterprise (WFOE) after initial entry as a joint venture (JV). Although most of MNC subsidiaries established as JVs in China in the 1980s and 1990s have been kept as JVs, some of them have been changed to WFOEs. For example, 11\%-15\% of Japanese JVs set up in Shanghai during the 1980s and 1990s were changed to WFOEs in the 2000s. The ability to manage the risks and exploit the opportunities that arise from ownership regulations can affect ownership-related strategic choices. Thus, MNC flexibility facilitates a post-entry mode change.

In the following, a theoretical framework will be developed combining network embeddedness, learning ownership regulations, MNC flexibility, and post-entry mode change. Then case studies will be used to exemplify the framework. Finally, a conclusion will be drawn according to the case studies.

\section{LITERATURE REVIEW}

\section{Network Embeddedness}

Embeddedness refers to a company's relations with, and reliance on, various types of networks. Embeddedness becomes a core issue in network research when various types of networks coexist around an organization and relate to one another (Halinen and Tornroos, 1998). Embedded ties refer to ongoing and exclusive relationships with one another. Powell (1990) divided inter-firm exchanges into market ties and network ties. The former are impersonal and constantly changing exchange partners while the latter are stable and keep close social relationships. Impersonal market transactions become concentrated and exclusive, forming dyadic embedded ties which assemble into extended networks of embedded ties. This means that each firm's ties and ties of these ties form an organization network (Uzzi, 1997), one that is embedded in a number of relationships with identifiable counterparts. This web of relationships can be called a network.

Granovetter (1985) criticized the markets' and hierarchies' argument that treats social structural impacts on market behavior as exceptions and combined the embeddedness approach with the economic approach. The combination can better explain economic behavior and competitiveness than the pure economic approach (Uzzi, 1997). The embeddedness perspective was first applied to the study of individuals and their networks and later to firms and their interorganizational networks (Gulati, 1999). In other words, the various types of networks can be divided to individual-level and organization-level. Moreover, "micronet-macronet embeddedness" (Halinen and Tornroos, 1998) categorizes networks from a different perspective. Micronet refers to the network composed of only business actors whereas macronet involves both business and non-business actors. 
Early research focused on networks only with inter-firm exchange relationships. This tradition continues in some of the later and even recent studies (e.g. Forsgren et al., 2005). Another stream of research studying inter-firm networks stressed strategic alliance networks (e.g. Hagedoorn and Duysters, 2002). Nevertheless, business networks in early research composed only of business actors have been expanded to networks with a variety of relationships (Welch and Wilkinson, 2004), including a firm's relationships with non-business actors and managers' social relations. These relationships are as important as inter-firm relationships.

Hallen (1992) classified networks into inter-firm level, organization-centered infrastructural level, and person-centered infrastructural level. Unlike inter-firm networks, infrastructural networks are characterized by weak ties, which are alive and can revive when required. Organization-centered infrastructural networks include a focal firm's relationships with non-business actors such as government, trade unions, industrial federations, and privateinterest associations. Person-centered infrastructural networks develop around specific individuals both as businessmen and as private persons; i.e., managerial ties defined as executives' interpersonal contacts with external entities (Peng and Luo, 2000; Zhang and Li, 2008). We regard Hallen's classification of network levels (1992) as the most appropriate cross-classification in terms of both individual/organization-level and micronet/macronet.

MNCs are treated as networks of both internal and external relationships (Dicken, 1998; Ghoshal and Bartlett, 1990). Internally, subsidiaries exchange information horizontally with each other and vertically with the headquarters, thus forming a communication network. Externally, different subsidiaries are embedded in different local networks (host government, competitors, customers, suppliers, financial institutions, intermediaries, alliance partners, etc.); thus the MNC, as a whole, tends to be embedded in differentiated networks simultaneously. Accordingly, a subsidiary of a MNC is part of a complex system of multiple linkages of internal and external relationships. However, internal units are not significantly different from external units to the individual subsidiary, as the subsidiary may depend on local actors to the same extent as or even more than on sister subsidiaries and headquarters (Forsgren et al., 2005). Thus, relationships between the internal units are regarded as interorganizational (Ghoshal and Bartlett, 1990). Likewise, we equally treat the units, both internal and external, of the MNC. Taking Hallen's classification (1992) into consideration, we highlight the three levels of a subsidiary's network; i.e., inter-firm network, including relationships with both internal units (sister subsidiaries and headquarters) and external business firms (e.g. suppliers, customers, alliance partners, consultants); organizationcentered infrastructural network, including relationships with external non-business organizations; person-centered infrastructural network, including managers' business ties and social ties both at the personal-level.

\section{Learning Ownership Regulations in China}

Ownership regulations of foreign investment in China are complex. In this paper, however, we focus on two primary aspects in order to examine effectively. One is various versions of "Catalogue for Guiding Foreign Investment in Industries" (the Catalogues) and the other is industry-specific ownership regulations of foreign investment.

Organizational learning is "the process within the organization by which knowledge about action-outcome relationships and the effect of the environment on these relationships is developed" (Duncan and Weiss, 1979, p. 84, in Weick, 1991). From this viewpoint, knowledge is the outcome of the learning process. Johanson and Vahlne (1977) classify the knowledge of international markets into objective knowledge easily acquired and experiential knowledge accumulated only through engaging in international operations. Eriksson et al. $(1997 ; 2000)$ identify three components of experiential knowledge - internationalization knowledge, business knowledge, and institutional knowledge. Foreign institutional knowledge, the experiential knowledge of government, institutional framework, rules, norms and values, concerns institutions found in foreign markets, foreign governments and bureaucracies, and the ways in which these work. It is insufficient to understand technical and commercial laws and norms in a foreign market without experiential institutional knowledge, as law enforcement in practice is even more important than what the law says. Knowledge about the changing ownership regulations of foreign investment in China could be contained in foreign institutional knowledge as the outcome of learning ownership regulations. In this paper, learning ownership regulations refers to obtaining, interpreting, or confirming ownership regulations of foreign investment in China. 


\section{Network Embeddedness and Learning Ownership Regulations}

One important source that MNC subsidiaries in emerging markets use to acquire foreign institutional knowledge is their networks (Elango and Pattnaik, 2007). These subsidiaries can obtain such knowledge, not only directly through their own experiences in both organizational-level and personal-level networking with local actors such as host government and business partners, but also through experiences of other firms in headquartersubsidiary and subsidiary-subsidiary networks. Institutional knowledge is "information about the governance structures in specific countries and their rules, regulations, norms and values" (Eriksson et al., 2000, p. 29). Information is among the most important functions of a firm's networks. Networks are a source of learning opportunities from outside the firm. Much of the critical information about foreign markets can be found in the network that a MNC develops, especially key actors within the network. Information flow is a type of network resource flow. Banerji and Sambharya (1996) stressed heavy information flows between network actors. The information flow includes information and knowledge not only gathered from connected firms, but also from nonbusiness actors in the network. When business relations are absent, infrastructural networks are essential to obtain information (Hallen, 1992). However, infrastructural networks can be more important than business relations with regard to acquiring institutional knowledge.

Previous studies have highlighted the link between networks and organizational learning (Ford, 1990). Particularly the learning process underlying internationalization activities is closely related to the development and utilization of foreign networks (Welch and Welch, 1996). Part of the key knowledge about foreign markets is created and maintained through network actors. Thus, networks are the external source of acquiring foreign institutional knowledge for MNCs. Although Johanson and Vahlne (2009) treat networks as vehicles in the learning institutional environment, little research has examined the influence of networks on learning such specific institutional condition as ownership regulations of foreign investment in China.

\section{MNC Flexibility}

Flexibility is a subject researched by a wide range of disciplines, from military strategy and economics through strategic management and decision theory, to child psychology and environmental research. Flexibility is also a multi-faceted concept, including adaptability, agility, versatility, resilience, and robustness (Bahrami and Evans, 2005). In other words, the content assigned to the concept varies from one author to another. Kogut (1985) argues that the MNC needs to create operational flexibility in order to profit from global strategies. Thus, it is also termed as strategic flexibility of the MNC. The concept of operational/strategic flexibility proposed by Kogut is captured and termed as multinational flexibility by Bartlett et al. (2008). They define multinational flexibility as the ability of a company to manage the risks and exploit the opportunities that arise from the diversity and volatility of the global environment. We comply with this definition. However, we focus on such a specific environment as the changing ownership regulations of foreign investment in China. Thus, flexibility is redefined as the MNC's ability to manage the risks and exploit the opportunities that arise from the changing ownership regulations of foreign investment in China; i.e., a specified formal institutional change in a specified country rather than a variety of environmental changes in the globe. In order to differentiate this flexibility from previous definitions, we term it MNC flexibility.

\section{Post-entry Mode Change}

Although there has been a lot research on initial entry mode choice, relatively little is studied about postentry change of foreign firms' ownership forms; i.e., changes in ownership forms of operation abroad after initial entry (Puck et al, 2009). It points to the mode change based on the same operation. For example, an initially established joint venture can be changed to a wholly-owned subsidiary through acquisition of shareholding owned by the local partner. Uppsala School advocates that the process of internationalization is incremental in the sequence of "export via an agent-sales subsidiary (acquisition of the agent or organized around employees of the agent) local production" (Johanson and Vahlne, 1977). In other words, if a MNC chooses exporting as the initial entry mode, it will give up exporting to set up a sales subsidiary and later change the same sales subsidiary to local production. The "post-entry changes of foreign firms' ownership forms" and "process of internationalization" can both indicate the way by which MNCs may change their operation modes after initially entering the foreign markets. We term this 
"post-entry mode change", which is defined as the MNC changes its mode of operation after initial entry into a foreign market. It should be noticed that "process of internationalization" includes more than a post-entry mode change. The sequential internationalization process (Johanson and Vahlne, 1977) can also include the situation that a MNC chooses exporting initially and later chooses sales subsidiary, and finally local production in subsequent entries.

In this paper, post-entry mode change is specified as the MNC changes to wholly-owned subsidiary (wholly foreign-owned enterprise, WFOE in China) after initial entry as joint venture (including Chinese-foreign Cooperative Enterprise, Chinese-foreign JV and IJV).

\section{A Theoretical Framework}

Networks are important for firm behavior and even more important for firm growth in transitional economies (Peng and Heath, 1996). Empirical studies provide evidence on the importance of network ties in China (Peng and Luo, 2000). In particular, relationship networks in China enable firms to overcome institutional instability in the face of regulatory changes (Luo, 2003). To put it differently, relationship networks of both domestic and foreign firms in China are a source of knowledge beyond what the policies say. This kind of knowledge, in accordance with Duncan and Weiss's definition of organizational learning, is the outcome of learning government policies, including acquiring, interpreting, or confirming such policies as ownership regulations. Thus, network embeddedness becomes vehicles in learning ownership regulations of foreign investment in China.

The information flow shaped by network embeddedness provides both opportunities and risks for firms and influences their strategic behavior (Gulati, 1999). Accordingly, the essence of learning ownership regulations is regarded as learning opportunities and risks that arise from the changing ownership regulations in China. The learning enables MNC subsidiaries to exploit these opportunities and manage these risks. In other words, learning ownership regulations through network embeddedness influences MNC's ability to exploit opportunities and manage risks that arise from the changing ownership regulations in China; that is, MNC flexibility. Furthermore, MNC flexibility is among the factors that impact post-entry mode change as firm capability of dealing with environmental opportunities and risks is important to its strategic choice. Thus, we develop the following theoretical framework:

Network embeddedness contributes to learning ownership regulations, which in turn promotes MNC flexibility, which in turn facilitates post-entry mode change (see Diagram 1).

Diagram 1: A Theoretical Framework

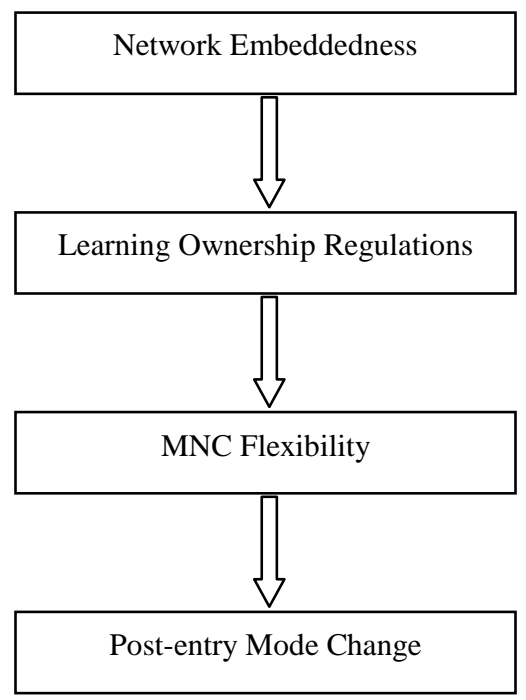

(C) 2012 The Clute Institute http://www.cluteinstitute.com/ 
Network embeddedness refers to the MNC subsidiary's relations with and reliance on the networks for learning ownership regulations, including inter-firm network, organization-centered infrastructural network and person-centered infrastructural network. Learning ownership regulations refers to acquiring, interpreting or confirming ownership regulations of foreign investment in China. In order to deal with the changing institutional environment, MNCs particularly their subsidiaries in China, need to utilize their relationship networks for obtaining thick information that discloses veracity and meaning behind what policy says. MNC flexibility has been defined in this paper as the MNC's ability to manage the risks and exploit the opportunities that arise from changing ownership regulations of foreign investment in China. Knowledge about these risks and opportunities is, in effect, the outcome of learning ownership regulations. Thus, learning ownership regulations can be linked to MNC flexibility. Through identifying opportunities and risks arisen from the changing ownership regulations, MNCs are enabled to handle these opportunities and risks. Post-entry mode change is specified as the MNC subsidiary in China has been changed to wholly foreign-owned enterprise (WFOE) after the initial entry as joint venture (JV, including Chineseforeign Cooperative Enterprise, Chinese-foreign JV, and International JV). Since the ability to handle opportunities and risks from changing environment impacts on corporate strategy, $M N C$ flexibility can exert influence over the status of post-entry mode change. Thus, network embeddedness, learning ownership regulations, MNC flexibility, and post-entry mode change can be put together into the above-stated framework.

\section{Case Studies}

Through Toyo Keizai (2010) and company websites, the author chose 20 Japanese MNC subsidiaries in Shanghai, all of which were set up as JVs during the 1980s and 1990s but were changed to WFOEs during the 2000s. A survey was first done by email, telephone and/or fax to get permission to interview their top managers. Four companies accepted the interview requirement and made appointments. Unfortunately upon arrival, the manager of one of the four companies that was to be interviewed left his office due to a sudden event in the company. Thus, in the end, only three managers were interviewed (A, B, C) - wholly owned ventures of three different Japanese MNCs. The interviews were semi-structured (see Appendix for interview questions).

The cases show that network embeddedness is indeed important to learning (acquiring, interpreting or confirming) the changing policies, such as ownership regulations of foreign investment. The mean scores of learning ownership regulations are high for all three companies ( 6 for company A, 6.5 for company B, and 5.5 for company C). As a result, network embeddedness contributes to learning ownership regulations. However, the extent of network embeddedness tends to be different in different subsidiaries (see Figures 1, 2, 3).

Company A is embedded in a network composed of seven actors, both individual and organization-level. Similarly, company B is connected with eight actors with regard to learning ownership regulations. However, there are only three actors in company C's network for learning ownership regulations. Thus, both company A and company B have much more sources of learning ownership regulations than company C. Nonetheless, the most important source to company $\mathrm{C}$ is its headquarter in Japan which may have many contacts for learning ownership regulations.

Corporate and regional headquarters are among the most important functions within the MNC. The corporate headquarter processes and transmits information to and from other parts of the MNC, while the regional headquarter intermediates between the corporate headquarter and its affiliates within its specific region (Dicken, 1998). Corporate headquarters handle relationships and information with high-level organizations, such as major business service providers (financial, legal or advertising) and major departments of foreign/domestic governments.

The scores of MNC flexibility are high for all three companies ( 7 for company A, 5 for company B, and 7 for company C). Accordingly, learning ownership regulations from network embeddedness promotes MNC flexibility. Furthermore, all three companies were changed from JVs to WFOEs. Thus, MNC flexibility promoted by learning ownership regulations facilitates post-entry mode change. For example, learning the Catalogues with the help of law consultants enhanced company B's ability to exploit opportunities obtained from the Catalogues, facilitating its post-entry mode change. 
Figure 1: Network of Company A

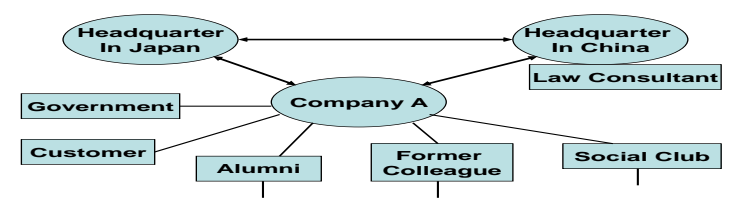

Figure 2: Network of Company B

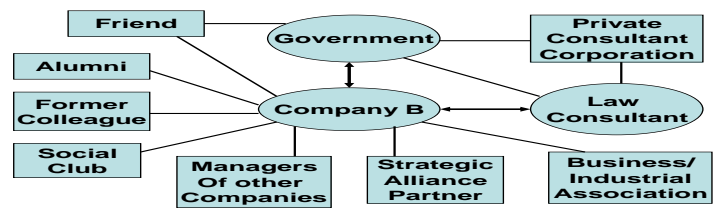

Figure 3: Network of Company C

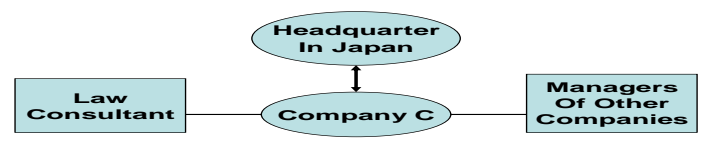

\section{CONCLUSION}

This paper proposed a theoretical framework that linked together network embeddedness, learning ownership regulations, MNC flexibility, and post-entry mode change. The case studies of three Japanese MNC subsidiaries in Shanghai exemplified the framework. Network embeddedness contributes to learning ownership regulations. Nonetheless, the extent of network embeddedness, which was measured by the number of actors in the network for learning ownership regulations, tends to be different in different subsidiaries. In turn, learning ownership regulations promotes MNC flexibility, which in turn, facilitates post-entry mode change. However, learning ownership regulations through subsidiary networks, and thus promoted MNC flexibility, may not be the most important to post-entry mode change.

\section{ACKNOWLEDGEMENT}

The author would like to thank her PhD supervisor team led by Professor Osamu Imada for their encouragement and academic support.

\section{AUTHOR INFORMATION}

Hua Ye, PhD student in Graduate School of Business Administration, Ritsumeikan University Japan. She got her Master's degree in International Business from University of Wolverhampton UK. She is also a lecturer in School of Public Health and Management, Chongqing Medical University China. E-mail: gr0038xv@ed.ritsumei.ac.jp 


\section{REFERENCES}

1. Bahrami, H. and Evans, S. (2005) Super-flexibility for knowledge enterprises. Berlin: Springer.

2. Banerji, K. and Sambharya, R.B. (1996) Vertical Keiretsu and international market entry: the case of the Japanese automobile ancillary industry. Journal of International Business Studies, 27(1), pp.89-113.

3. Bartlett, C.A., Ghoshal, S. and Beamish, P.W. (2008) Transactional management: Text, cases, and readings in cross-border management. 5th ed., Singapore: McGraw-Hill.

4. Blankenburg, D. and Johanson, J. (1992) Managing network connections in international business. Scandinavian International Business Review, 1(1), pp. 5-19.

5. Dicken, P. (1998) Global shift: Transforming the world economy. 3 rd ed. New York: Guilford Press.

6. Elango, B. and Pattnaik, C. (2007) Building capabilities for international operations through networks: A study of Indian firms. Journal of international business studies, 38, pp. 541-555.

7. Eriksson, K., Johanson, J., Majkgard, A. and Sharma, D.D. (1997) Experiential knowledge and cost in the internationalization process. Journal of international business studies, 28(2), pp. 337-360.

8. Eriksson, K., Johanson, J., Majkgard, A. and Sharma, D.D. (2000) Effect of variation on knowledge accumulation in the internationalization process. International studies of management and organization, $30(1)$, pp. 26-44.

9. Ford, D. (1990) Understanding Business Markets: Interaction, Relationships and Networks. London: Academic Press.

10. Forsgren, M., Holm, U. and Johanson, J. (2005) Managing the embedded multinational-A business network view. Cheltenham: Edward Elgar.

11. Ghoshal, S. and Bartlett, C.A. (1990) The multinational corporation as an interorganizational network. Academy of management review, 15 (4), pp. 603-625.

12. Granovetter, M. (1985) Economic action and social structure: The problem of embeddedness. American journal of sociology, 91(3), pp. 481-510.

13. Gulati, R. (1999) Network location and learning: the influence of network resources and firm capabilities on alliance formation. Strategic management journal, 20, pp. 397-420.

14. Hagedoorn, J. and Duysters, G. (2002) Learning in dynamic inter-firm networks: the efficacy of multiple contacts. Organization studies, 23(4), pp. 525-548.

15. Halinen, A. and Tornroos, J.-A. (1998) The role of embeddedness in the evolution of business networks. Scandinavian journal of management, 14 (3), pp. 187-205.

16. Hallen, L. (1992) Infrastructural networks in international business. In M. Forsgren and J. Johanson, Managing networks in international business (pp. 77-92). Philadelphia, PA: Gordon and Breach.

17. Johanson, J. and Vahlne, J. (1977) The internationalization process of the firm-A model of knowledge development and increasing foreign market commitments. Journal of international business studies, 8(1), pp. 23-32.

18. Johanson, J. and Vahlne, J. (2009) The Uppsala internationalization process model revisited: From liability of foreignness to liability of outsidership. Journal of international business studies, 40, pp. 1411-1431.

19. Kogut, B. (1985) Designing global strategies: profiting from operating flexibility. Sloan management review, Fall, pp. 27-38.

20. Luo, Y. (2003) Industrial dynamics and managerial networking in an emerging market: The Case of China. Strategic management journal, 24 (13), pp. 1315-27.

21. Peng, M.W. and Heath, P.S. (1996) The growth of the firm in planned economies in transition: institutions, organizations, and strategic choice. Academy of management review, 21 (2), pp. 492-528.

22. Peng, M. W. and Luo, Y. (2000) Managerial ties and firm performance in a transition economy: The nature of a micro-macro link. Academy of management journal, 43(3), pp. 486-501.

23. Powell, W.W. (1990) Neither market nor hierarchy: Network forms of organization. Research in organizational behavior, 12, pp. 295-336.

24. Puck, J.F., Holtbrugge, D. and Mohr, A.T. (2009) Beyond entry mode choice: explaining the conversion of joint ventures into wholly owned subsidiaries in the People's Republic of China. Journal of international business studies, 40, pp. 388-404.

25. Rangan, S. (2000) Search and deliberation in international exchange: micro foundations to some macro patterns. Journal of international business studies, 31(2), pp. 205-222. 
26. Uzzi, B. (1997) Social structure and competition in interfirm networks: the paradox of embeddedness. Administrative science quarterly, 42, pp. 35-67.

27. Weick, K. E. (1991) The nontraditional quality of organizational learning. Organization Science, 2 (1), pp. 116-124.

28. Welch, D.E. and Welch, L.S. (1996) The internationalization process and networks: a strategic management perspective. Journal of International Marketing, 4(3), pp. 11-28.

29. Welch, C. and Wilkinson, I. (2004) The political embeddedness of international business networks. International marketing review, 21(2), pp. 216-231.

30. Zhang, S. and Li, X. (2008) Managerial ties, firm resources, and performance of cluster firms. Asia pacific journal of management, 25 , pp. 615-633. 


\section{APPENDIX}

\section{Interview Questions}

1. Has your company ever changed from joint venture (JV) to wholly foreign-owned enterprise (WFOE)?

\section{Yes ( ) No( )}

the year of establishing a JV:

the year of becoming a WFOE (if applicable):

2. Which of the following relationships are important to your obtaining, interpreting and confirming foreign ownership regulations in China?

( ) relationships with suppliers

( ) relationships with customers

( ) relationships with strategic alliance partners with which your company set up contractual agreements or equity joint ventures

( ) relationships with headquarter in China (if applicable)

( ) relationships with headquarter in Japan

( ) relationships with sister subsidiaries in China

( ) relationships with law consultants

( ) relationships with Chinese government

( ) relationships with business associations

( ) relationships with managers of other companies

( ) relationships with friends (please state what kind of friends; for example, friends in social clubs, friends in the government, etc.)

( ) other relationships (please state)

3. To what extent do you know ownership regulations of foreign investment in China?

(1) Industry-specific ownership regulations

very little $1223 \quad 45667$ very much

(2) Catalogue for Guiding Foreign Investment in Industries (the Catalogues)

very little $\begin{array}{lllllllllll}1 & 2 & 3 & 4 & 5 & 6 & 7 & \text { very much }\end{array}$

4. To what extent do you agree with the following statement: "How a policy is enforced in practice at a particular time by a particular government agency is more important than what the policy says."

very disagree 122345567 very agree 